\title{
Instrukcje rodzicielskie Wacława Rzewuskiego dla syna Seweryna oraz córek Teresy i Ludwiki z lat 1754 i 1763/64
}

\begin{abstract}
Parental instructions of Wacław Rzewuski for his son Seweryn and daughters from the years 1754 and 1763/64

The education of younger generations had long and rich traditions in the old Polish aristocratic Rzewuski family. The domestic and foreign education of sons in particular played a major role in building the power and social position of the family. The main purpose of this article is to present hitherto unknown sources on the history of the education of members of this family. Between 1754 and 1763 (or 1764) four instructions have survived, written by Wacław Rzewuski for his son Seweryn and two daughters: Teresa Karolina and Ludwika Maria Róża. The first instruction for Seweryn Rzewuski comes from the period of his studies in Warsaw (1754), when the young magnate attended the college of Theatines. In this piece of writing, the father gives detailed instructions on the civic education for his son. This instruction contains advice on how to behave properly during social gatherings and religious ceremonies. It also refers to the rules of the moral education of the young boy. The second instruction for Seweryn contains advice on the protection of the family residences in Podhorce and Olesko and was associated with the political situation in which Waclaw Rzewuski and his sons lived in the years from 1763-1764. However, the two instructions for his daughters are a real rarity. Wacław Rzewuski paid great attention to their security and safety and very good presence. One of the instructions was devoted to the conditions and circumstances for short journeys by the daughters to a nearby church or monastery. In particular, it concerns the staff of the daughters' traveller suite. Another talks about being cautious with fire during their stay in the palace in Podhorce. Both instructions are unique documents of the realities of daily life and domestic trips by young women from the aristocratic sphere, and a father's expectations with regard to their proper behaviour and maintaining good manners.
\end{abstract}

Keywords: modern epoch, education of Polish aristocracy, parental instructions in Poland, Wacław Rzewuski, Seweryn Rzewuski, daughters of Wacław Rzewuski

W staropolskim modelu wychowania synów szlacheckich i magnackich w XVIII w. tradycyjnie wyróżnia się trzy następujące po sobie etapy: edukację domową prowadzoną 
pod kierunkiem wynajętych nauczycieli, kształcenie szkolne, głównie w kolegiach jezuickich, pijarskich lub teatyńskich i wreszcie wyjazd zagraniczny w postaci podróży edukacyjnej. Czasami ten schemat jest upraszczany jedynie do dwóch elementów obejmujących odpowiednio edukację domową i szkolną (lub tylko domową prowadzoną przez prywatnych nauczycieli) oraz wyjazd zagraniczny bądź pobyt na dworze ${ }^{1}$. Wszystkie komponenty tego schematu wystąpiły w procesie edukacji synów wojewody krakowskiego $\mathrm{i}$ hetmana polnego, a następnie wielkiego koronnego Wacława Rzewuskiego. Z jego jedynego małżeństwa z wojewodzianką czernichowską Anną Lubomirską (ok. 1717-1763) narodziło się dziesięcioro dzieci, w tym aż siedmiu synów, z których jedynie trzech dożyło wieku dorosłego ${ }^{2}$. Biorąc pod uwagę wychowanie najmłodszego z synów Wacława Rzewuskiego, należy rozpatrywać je w szerszym kontekście podejścia do wykształcenia w warstwie magnackiej, której przedstawiciele traktowali tę dziedzinę życia jako absolutny wymóg realizacji stanowego modelu egzystencji, pieczętowanego osiągnięciem określonego poziomu umysłowości i obycia otwierającego drogę do kariery urzędniczej bądź wojskowej ${ }^{3}$. Adresatem analizowanej poniżej instrukcji ojcowskiej jest starosta doliński Seweryn Rzewuski (1743-1811), późniejszy hetman polny koronny i jeden z liderów konfederacji targowickiej ${ }^{4}$. W dalszej części artykułu nasza uwaga skupi się na dwóch instrukcjach skierowanych do córek. Celem jest analiza treści mało lub wcale dotąd nieznanych w literaturze przedmiotu, instrukcji wychowawczych Wacława Rzewuskiego znajdujących się wśród rękopisów archiwum rodzinnego z zamku w Podhorcach. Na podkreślenie zasługuje obfita twórczość instruktażowa Rzewuskiego, która świadczyć może zarówno o pedagogicznych ambicjach tego autora, jak i dobrym stanie zachowania archiwaliów rodzinnych. Sam fakt jego aktywności na tym polu wydaje się oczywistą konsekwencją dbałości rodzica o właściwy rozwój dorastających dzieci pozostających pod jego opieką oraz niezbywalne prawo ojca do udzielania wskazówek i nakazów potomstwu, które należało wypełniać z całkowitym posłuszeństwem uznawanym wówczas za absolutny obowiązek dzieci ${ }^{5}$.

Z połowy XVIII w. zachowało się w rękopisie kilka instrukcji rodzicielskich, a ściślej mówiąc ojcowskich przeznaczonych dla dzieci Wacława Rzewuskiego. Dysponujemy przede wszystkim tekstami kilku instrukcji skierowanych do najmłodszego spośród żyjących synów, czyli Seweryna. Wśród nich na szczególną uwagę zasługuje zbiór pouczeń noszący znamienny tytuł Informacyja synowi memu jak się ma sprawować w Warszawie

1 Ł. Kurdybacha, Pedagogika szlachecka $w$ XVI i XVII w. w świetle instrukcji rodzicielskich, w: idem, Pisma wybrane, oprac. J. Miąso, t. 3, Warszawa 1976, s. 33-35.

2 Z. Zielińska, Rzewuski Wacław h. Krzywda (1706-1779), Polski Słownik Biograficzny (dalej cyt.: PSB), t. 34, 1992-1993, s. 179.

${ }^{3}$ W. Czapliński, J. Długosz, Życie codzienne magnaterii polskiej w XVII w., Warszawa 1982, s. 23-30.

${ }^{4}$ Z. Zielińska, Rzewuski Seweryn, PSB, t. 34, 1992-1993, s. 138-151.

${ }_{5}$ B. Parysiewicz, Z badań nad rozwojem polskiej myśli pedagogicznej o wychowaniu w rodzinie, w: Wychowanie w rodzinie od starożytności po wiek XX. Materiały z konferencji naukowej Katedry Historii wychowania czerwiec 1993, pod red. J. Jundziłła, Bydgoszcz 1994, s. 214. 
dana $w$ Jezierny die 14 Junii R.P $1754^{6}$. Jest to szczegółowy program dnia oraz wykaz oczekiwań co do prywatnej nauki i właściwego zachowania się podczas publicznych spotkań w stolicy, jakie ojciec stawiał przed swoim, wówczas liczącym zaledwie jedenaście lat, synem. Jedynie tytułem informacji należy wspomnieć, że Wacław Rzewuski był też autorem wielu instrukcji o charakterze politycznym, napisanych w latach 60. XVIII w., które miały kierować aktywnością młodego Seweryna w sferze publicznej i państwowej7. Spod pióra Wacława Rzewuskiego wyszły również instrukcje podróżne dla synów udających się w wojaże edukacyjne po Europie. Znane są dwa dokumenty instruktarzowe tego typu przeznaczone dla synów, Józefa ${ }^{8}$ oraz jego młodszego brata Seweryna, znanego później targowiczanina i jednego z bohaterów tegoż opracowania9. Ponieważ są to pouczenia związane z wyjazdami zagranicznymi, nie będziemy ich tutaj rozpatrywać samoistnie $z$ tej racji, że są to odrębne gatunkowo typy instrukcji stanowiące odmienny rodzaj literatury poradnikowej.

Przystępując do przedstawienia treści i znaczenia tytułowych instrukcji, należy kilka słów poświęcić wychowaniu domowemu i szkolnemu młodych Rzewuskich. Wśród guwernerów zatrudnianych przez ojca do nauki małoletnich magnatów można wyróżnić kilka znanych postaci ze środowiska staropolskich preceptorów. Z pewnością najwybitniejszą osobistością w tym gronie był francuski ksiądz Ludwik Antoni Caraccioli, pełniący zresztą opiekę mad wszystkimi trzema synami Wacława Rzewuskiego zarówno w kraju, jak i za granicą już od 1754 r. Jego rola w wychowaniu Rzewuskich była szczególnie istotna podczas europejskich wojaży ${ }^{10}$. Guwernerem młodych Rzewuskich miał być wcześniej znany pijar Ludwik Stanisław Górski, stojący wówczas u progu swojej nauczycielskiej kariery ${ }^{11}$. Późniejszy biskup sufragan pomorski gwarantował z pewnością wysoki poziom edukacji magnackich potomków, biorąc pod uwagę jego wykształcenie i początki nauczania wymowy oraz sztuk pięknych w zreformowanych kolegiach pijarskich. Pewne wątpliwości budzi natomiast informacja zawarta w jego biogramie mówiąca, że uczył tylko dwóch synów: Józefa i Seweryna ${ }^{12}$. Trzeba raczej przyjąć, iż opieka dotyczyła zapewne przez pewien okres wszystkich trzech synów, a co bardziej prawdopodobne tylko dwóch starszych, czyli Józefa oraz Stanisława, gdyż to oni zostali wysłani w podróż zagraniczną jeszcze w 1755 r., podczas gdy Seweryn wyruszył w nią dopiero cztery lata później.

${ }^{6}$ Archiwum Narodowe w Krakowie, oddział na Wawelu (dalej cyt. ANK), Archiwum Podhoreckie (dalej cyt.: APodh) II 230, s. 215-216; dalej cyt.: Informacyja synowi memu jak się ma sprawować w Warszawie.

7 Szerzej zob. na ten temat K. Maksimowicz, Młodość i początki działalności publicznej Seweryna Rzewuskiego (lata 1743-1767), ,Ze skarbca kultury” 1989, z. 48, s. 75-111.

${ }^{8}$ Informacya synowi memu Józefowi dana w Ppodhorcach R.P 1755 D. 14 Augusti; Muzeum Narodowe w Krakowie, rkps 22, k. 207v.-208.

9 Informacya synowi memu Sewerynowi do Wiednia i dalszych cudzych krajów jadącemu dana dnia 14 februarii roku pańskiego 1759 w Podhorcach; Archiwum Narodowe w Krakowie (Wawel), APodh I 126, s. 383-384

${ }^{10}$ H. Waniczkówna, Caraccioli Ludwik Antoni de (1721-1803), PSB, t. 3, 1937, s. 202-203.

11 I. Zatorska, Les Polonais en France 1696-1795. Bio-bibliographie provisoire, Warszawa 2000, s. 37.

12 P. Czaplewski, Górski Ludwik Stanisław (1725-1799), PSB, t. 8, Wrocław 1959-1960, s. 448. 
Wracając do instrukcji z 1754 r. należy nadmienić, że jest to dokument instruktażowy, sporządzony najwcześniej spośród czterech tutaj rozpatrywanych, według obecnego stanu wiedzy. Powstał on w newralgicznym momencie życia i edukacji Seweryna Rzewuskiego, który właśnie pobierał nauki w warszawskim kolegium teatynów i niebawem miał rozpocząć edukację domową pod kierunkiem cieszącego się dużym uznaniem guwernera Ludwika Antoniego Caracciolego ${ }^{13}$. W kilka lat później został on preceptorem podróżnym Rzewuskiego, towarzysząc mu w jego Grand Tour po Europie. Wybór teatyńskiej placówki edukacyjnej był decyzją podyktowaną nie tylko względami wychowawczymi, ale w dużej mierze zapewne chęcią zamanifestowania prestiżu rodowego Rzewuskich oraz ich rosnącej pozycji majątkowej i znaczenia politycznego, gdyż kolegium to przyciągało głównie najzamożniejszych uczniów z grona magnatów i bogatej szlachty ze względu na wysokie czesne ${ }^{14}$. Teatyni warszawscy mieli jeszcze istotny atut. Oferowali wówczas ciągle nowe, mimo już blisko dwudziestoletniego stażu swojej szkoły, europejskie spojrzenie na problem potrzeb edukacyjnych i związaną z nimi konieczność reform na tym polu ${ }^{15}$.

Naukę w teatyńskim kolegium w Warszawie Seweryn rozpoczął być może jeszcze przed 1754 r. W każdym razie jesienią tego roku nadal uczył się w tej szkole, o czym świadczy jego udział w wystawieniu dwóch sztuk teatralnych. 26 września 1754 r. wystąpił w adaptacji tragedii włoskiej Łaskawość Tita cesarza, autorstwa Pietra Metastasio, wcielając się w rolę jednego z ośmiu żołnierzy rzymskich. Zaledwie dwa dni później zagrał kwestię kobiecą Hortensji, córki Gricharda w komedii francuskiej Zrzędny Hałaśnik, napisanej przez Davida-Augustina Brueysa i Jeana Palaparta ${ }^{16}$. O ciągłości edukacyjnego programu Wacława Rzewuskiego świadczy fakt, że wcześniej w tej szkole teatyńskiej uczyli się starsi bracia Seweryna, Józef, a także Stanisław ${ }^{17}$. Kolegium to, działające od lat 30 XVIII w., cieszyło się wówczas renomą prestiżowej szkoły z nowatorskimi programami kształcenia i wysokim poziomem nauczania ${ }^{18}$. Decyzję Wacława Rzewuskiego o wyborze teatyńskiego kolegium jako miejsca nauki dla najmłodszego syna należy uznać za efekt świetnej orientacji tego magnata na staropolskim rynku edukacyjnym połowy XVIII w. Teatyni stworzyli bowiem pionierski zakład wychowawczo -edukacyjny, w którym wdrażali najnowsze zachodnioeuropejskie trendy kształceniowe, wzorując się na elitarnych kolegiach szlacheckich. Na niektórych polach wyprzedzili pod

${ }^{13}$ Z. Zielińska, Rzewuski Seweryn h. Krzywda (1743-1811), s. 138-139.

${ }^{14}$ K. Maksimowicz, W sprawie Collegium Varsaviense ojców teatynów, w: Europejskie zwiąki dawnego teatru szkolnego i europejska wspólnota dawnych kalendarzy, pod red. I. Kadulskiej, Gdańsk 2003, s. 92.

${ }^{15}$ K. Puchowski, Przemiany w szkolnictwie zakonnym Rzeczypospolitej czasów saskich, w: Między barokiem a oświeceniem. Edukacja, wykształcenie, wiedza, pod red. S. Achremczyka, Olsztyn 2005, s. $20-21$.

${ }^{16}$ Dramat staropolski od początków do powstania sceny narodowej. Bibliografia, t. 2 , cz. 2: Programy drukiem wydane do r. 1765. Programy teatru pijarskiego oraz innych zakonów i szkót katolickich, opr. W. Korotaj, J. Szwedowska, M. Szymańska, Wrocław 1978, s. 322-323.

17 S. Graciotti, Od Renesansu do Oświecenia, Warszawa 1991, t. 2, s. 44.

${ }_{18}$ Ł. Kurdybacha, Kolegium teatynów w Warszawie, w: Historia wychowania, t. 1, pod red. Ł. Kurdybachy, Warszawa 1967, s. 579-581. 
względem innowacyjności programów nauczania czołowe zakony kształcące w Polsce reprezentantów warstw uprzywilejowanych, czyli jezuitów i pijarów ${ }^{19}$.

Powierzanie nauczycielom kolegiów zakonnych opieki nad wykształceniem i wychowaniem synów magnackich i szlacheckich, powszechnie realizowane w Polsce XVIII w., tworzyło oczywiste mechanizmy powiązań oraz kontroli sprawowanej przez jezuitów, pijarów czy wreszcie teatynów nad kształceniem elit społecznych. Rzewuski nie był pod tym względem wyjątkiem. Wpływ, wywodzących się z Włoch, teatynów zaznaczył się też w kolejnych jego decyzjach dotyczących wykształcenia synów, a mianowicie w desygnowaniu preceptora podczas zagranicznej podróży edukacyjnej, którym został mający włoskie korzenie francuski ksiądz ze zgromadzenia oratorian, Ludwik Antoni Caraccio$\mathrm{li}^{20}$. W 1755 r. wyjechał on ze starszymi braćmi Seweryna (Józefem i Stanisławem), podczas gdy ten pierwszy stawiał wówczas w kraju pierwsze kroki na ścieżce kariery wojskowej ${ }^{21}$. Trójstopniowy schemat edukacji, obejmujący etapy wychowania domowego, szkolnego i podróżnego był wzbogacany o element kształcenia podczas pobytów na dworach krajowych i zagranicznych. Ten model kształcenia był powielany, w różnych wariantach i rozwiązaniach szczegółowych, w praktyce edukacyjnej wielu polskich familii magnackich. Świetnym przykładem żywotności tych idei był przypadek edukacji młodych Mniszchów w latach 60 XVIII w., którzy decyzją swej matki Katarzyny Mniszchowej $\mathrm{z}$ Zamoyskich nauczanie szkolne rozpoczęli $\mathrm{z}$ kolei $\mathrm{w}$ stołecznym pijarskim Collegium Nobilium, kontynuując je później podczas studiów zagranicznych. Również w tym wypadku opiekę nad młodymi magnatami złożono w ręce cudzoziemskich guwernerów, dając wyraz popularności europejskich wzorców kształcenia w kręgach polskiej elity $^{22}$.

Jak w wynika z jej tytułu, instrukcja dla Seweryna z 1754 r. została napisana w Jezierzanach w dniu 14 czerwca, w kompleksie ukraińskich dóbr należących do Wacława Rzewuskiego ${ }^{23}$. Tekst nie precyzuje miejsca pobytu Seweryna w tamtym momencie, lecz można domniemywać, że przebywał on wówczas u boku ojca, być może korzystając z przerwy w nauce w warszawskim kolegium teatynów i przygotowywał się do powrotu do stolicy. Jeśli Seweryn nie bawił wówczas w Warszawie, to z pewnością pozostawał u boku ojca, który pragnął mieć chłopca jak najbliżej, czemu dał też wyraz w instrukcji, gdzie wymagał od syna, aby ten stale był ode mnie niedaleko, i na oku moim ${ }^{24}$. Pobyt w Warszawie trwał zapewne około miesiąca lub dwóch, gdyż w lipcu Wacław konferował z ministrem saskim Brühlem, a już w sierpniu nadzorował przebieg sejmików cheł-

19 K. Puchowski, Edukacja ,losem urodzenia wyznaczonych $w$ warszawskim kolegium teatynów (17371785), w: Między barokiem a oświeceniem. Sarmacki konterfekt, pod red. S. Achremczyka, Olsztyn 2002, s. 79-81, 94.

${ }^{20}$ H. Waniczkówna, Caraccioli Ludwik Antoni de (1721-1803), PSB, t. 3, Kraków 1937, s. 202.

${ }^{21}$ Cztery lata później Caraccioli został również preceptorem podróżnym Seweryna; L. Rzewuski, Kronika Podhorecka 1706-1779, Kraków 1860, s. 36.

22 M. Bratuń, ,, Ten wykwintny, wykształcony Europejczyk”. Zagraniczne studia i podróże edukacyjne Michała Jerzego Wandalina Mniszcha w latach 1762-1768, Opole 2002, s. 39-41.

23 Słownik Geograficzny Królestwa Polskiego i Innych Krajów Stowiańskich, t. 3, Warszawa 1882, s. 571.

${ }^{24}$ Informacyja synowi memu jak się ma sprawować w Warszawie, s. 215. 
mskich i podolskich, pilnując realizacji politycznych planów króla ${ }^{25}$. Jednakże najważniejszym powodem przyjazdu do stolicy były przygotowania do udziału w sejmie zwyczajnym (ostatecznie zerwanym), który obradował w Warszawie w dniach 30 września - 31 października ${ }^{26}$. Celem spisania instrukcji ojcowskiej było ujęcie w drobiazgowe karby przepisów praktycznego nabywania kompetencji dworskich i politycznych przez młodego Seweryna. Pobyt w Warszawie u boku ojca miał być realizacją postulatu kształcenia umiejętności społeczno-politycznych, które od czasów odrodzenia uważano za kluczowe w przygotowaniu do przyszłej kariery urzędniczej, a obejmowało ono zdobywanie doświadczenia i wiedzy obywatelskiej przez przypatrywanie się obradom sejmowym czy sejmikowym, wysłuchiwanie mów, czy przypatrywanie się prowadzeniu politycznych negocjacji ${ }^{27}$. Dodajmy, że posłem na ten sejm z województwa podolskiego został, starszy brat Seweryna, starosta drohobycki Józef, mający wówczas piętnaście lat ${ }^{28}$. Z powyższych powodów instrukcję dla Seweryna należy traktować jako narzędzie stymulujące osiąganie erudycji dworskiej, czyli ideału obywatela i kompetencji statysty - przyszłego męża stanu oraz urzędnika. Głównym składnikiem tego procesu była ,paideia” polegająca na kształceniu umysłu i charakteru, życiu zgodnym z prawem oraz przygotowaniu się do służby publicznej będącej uosobieniem patriotyzmu i pracy dla ojczyzny ${ }^{29}$.

Instrukcja ojcowska bardzo precyzyjnie określała ramowy plan dnia młodego chłopca, jakim był wówczas Seweryn. W kolejnych punktach uwidacznia się przywiązywanie przez ojca dużej wagi do bezwzględnej dyscypliny czasowej i punktualności. Codzienne zajęcia zostały zaplanowane z drobiazgową szczegółowością, nie pozostawiając właściwie miejsca na wahania w kwestii zadań przewidzianych na konkretną porę ani ich ustalonej kolejności. Dzień miał się rozpoczynać o godzinie piątej rano, a już pół godziny później syn miał się pojawić w sypialni ojca, aby otrzymać konkretne polecenia. Przy czym pośpiech był na tyle istotny, iż ojciec sugerował nawet ograniczenie porannej toalety do niezbędnego minimum: o pół do szóstej u mnie być trzeba w sukni jakiej podlejszej $i$ nie ubrawszy się tylko raptem ${ }^{30}$. Przez półtorej godziny Seweryn miał się uczyć przedmiotów i zagadnień zaordynowanych przez ojca. Dopiero o godzinie siódmej zalecano mu ubrać się należycie, a pozostałą część czasu do godziny dziewiątej wykorzystać na lekturę. Następnie miał się on ponownie stawić u ojca i udać się z nim na przewidziane spotkania lub asystować przy wizytach składanych ojcu w jego rezydencji. Wacław Rzewuski pragnął sprawować nad zachowaniem syna kontrolę absolutną, aby uniknąć jakichkolwiek niewłaściwych postaw czy znajomości. Zalecał także synowi utrzymywa-

25 Z. Zielińska, Rzewuski Wacław, s. 171.

${ }^{26}$ W. Konopczyński, Chronologia sejmów polskich 1493-1793, Kraków 1948, s. 165.

27 D. Żołądź, Ideaty edukacyjne doby staropolskiej. Stanowe modele i potrzeby edukacyjne szesnastego i siedemnastego wieku, Warszawa-Poznań 1990, s. 62-63.

${ }_{28}$ Diarjusze sejmowe z wieku XVIII, t. III, Diariusze sejmów z lat 1750, 1752, 1754 i 1758, wyd. W. Konopczyński, s. 286.

${ }_{29}$ J. Poraziński, ,Statysta głęboki”. Kilka uwag o erudycji staropolskich polityków, w: Między barokiem a oświeceniem. Edukacja, wykształcenie, wiedza, pod red. S. Achremczyka, Olsztyn 2005, s. 9-11.

${ }^{30}$ Informacyja synowi memu jak się ma sprawować w Warszawie, s. 215. 
nie i zawieranie jedynie przydatnych znajomości i nawiązywanie pożądanych kontaktów towarzyskich, czemu miał służyć nakaz obracania się wyłącznie „między słusznemi ludźmi”. Zresztą pozostawiał sobie także decyzję odnośnie tego z kim Seweryn może utrzymywać relacje czy prowadzić rozmowy, zalecając mu zawsze kultywowanie zasad dobrego wychowania, co miała wyrażać skromność i grzeczność w obejściu i rozmowach oraz okazywanie wszystkim należytego szacunku³ ${ }^{31}$ Nakaz powściągliwości i roztropności w formułowaniu wypowiedzi był zresztą powszechnie podnoszony w instrukcjach dla synów magnackich i szlacheckich jako jeden z podstawowych wymogów dobrego zachowania już od najmłodszych lat ${ }^{32}$. Jakkolwiek brak w poniższej instrukcji sformułowań szczegółowych można domniemywać, że owe kontakty z właściwymi ludźmi były rozumiane przez autora jako nabywanie kompetencji odpowiedniego zachowania i postępowania w środowisku szlachecko-magnackim. Ten element mógł być z kolei postrzegany jako wstęp do właściwego wychowania patriotycznego objawiającego się troską o dobro Rzeczypospolitej i narodu szlacheckiego ${ }^{33}$. Należy również zaznaczyć, że pragnienie otoczenia syna ludźmi życzliwymi wywodzącymi się z odpowiednich kręgów społecznych i towarzyskich było zamiarem powszechnie przejawianym przez ojców wysyłających synów do szkół tak krajowych, jak i zagranicznych ${ }^{34}$.

Regulacje odnoszące się do właściwej konduity w kręgach warszawskiej socjety zabraniały młodemu Sewerynowi uprawiania wszelkich gier hazardowych, wyjąwszy przypadki takich rozrywek w ojcowskiej rezydencji i za jego wiedzą. Wacław nakładał również na syna znaczne ograniczenia w ilości spożywanego alkoholu, pozwalając mu jedynie na wypicie w trakcie obiadu lub wieczerzy zaledwie dwóch kieliszków wina zmieszanego z wodą. Wykluczał również możliwość spożywania wieczornego posiłku poza domem, wyznaczając godzinę wpół do dziesiątej jako porę udania się na spoczynek. W przypadku uczestniczenia w imprezach towarzyskich, chodziło tu zapewne o bale, ansamble czy spektakle teatralne, Seweryn miał się kłaść spaść o godzinie dziesiątej. Wacław wykazywał zresztą daleko posuniętą troskę o bezpieczeństwo syna, przykazując mu aby w trakcie dużych zgromadzeń publicznych, np. podczas mszy z udziałem monarchy, trzymał się blisko niego, co miało ustrzec chłopca przed zagubieniem się w tłumie ${ }^{35}$. Analizując powyższe zalecenia Wacława Rzewuskiego dla najmłodszego syna, należy uznać je przede wszystkim za próbę wcielenia w życie ideału honnête homme. Wykrystalizował się on we Francji jako wzorzec dwornego zachowania szlachetnie urodzonego kawalera i był niezbywalnym komponentem podręczników dobrego wychowania, wyrażającym się w szerokiej gamie zalet charakteru i postaw: grzeczności, obyczajności, bły-

\footnotetext{
31 z modestyją i respektem dla wszystkich; Ibidem.

${ }^{32}$ P. Gad, „Ojcowskim sercem i słowem” - Instrukcja wychowawcza autorstwa Hieronima Floriana Radziwilta, „Ogrody Nauk i Sztuk” 2016, 6, s. 217.

33 S. Łempicki, Polski ideat wychowawczy, Lwów-Warszawa 1937, s. 10-11.

${ }^{34}$ D. Żołądź, Rodzina szlachecka jako środowisko wychowawcze (XVI-XVII w.), w: Wychowanie w rodzinie od starożytności po wiek XX, s. 183.

35 „Na mszy królewskiej za mną zawsze stać ma syn mój i mnie pilnować, żebym go nie odjachał”; Informacyja synowi memu jak się ma sprawować w Warszawie, s. 215.
} 
skotliwości, umiarkowania oraz zachowywania dobrych manier i zasad honorowego postępowania czy umiejętności okazywania szacunku. Ten specyficzny model bycia, genetycznie wynikający z kondycji społecznej i stanowego statusu magnata, należącego z urodzenia do najbardziej elitarnej sfery, miał gwarantować uznanie towarzyskie oraz sukcesy polityczne ${ }^{36}$. Dzięki powyższej instrukcji możemy poznać wersję ideału honnête homme przeniesioną w realia polskie XVIII w. zastosowaną do konkretnego odcinka czasu i określonych aktywności publiczno-towarzyskich.

Kwestiom bezpieczeństwa i nadzoru poświęcona została odrębna część instrukcji zatytułowana „Pajucy”. Dla eliminacji zagrożeń i zachowania pozorów należytej ostentacji Wacławowi i Sewerynowi mieli usługiwać lokaje i stangreci ubrani w jednakowe liberie. Między innymi mieli oni zawsze trzymać straż przed sypialniami magnatów, a w przypadku syna także wewnątrz nich. Bezpośredni i stały nadzór sług ojca miał zapewnić właściwy rozwój sfery psychiczno-moralnej syna i skutecznie odgrodzić go od wszelkich pokus. Potwierdza to tezę, że w praktyce formacja moralna była naczelnym zadaniem staropolskiego programu edukacyjnego w hierarchii ważności realizowanym zawsze przed kształceniem intelektualnym ${ }^{37}$. Fakt, iż sługami byli pajucy zdradza pewną predylekcję Wacława Rzewuskiego do mody orientalnej. Pajukami było kilku Polaków i jeden autentyczny Turczyn. Do ich zadań należała ochrona Rzewuskich zarówno w ich rezydencji jak i w podróży oraz pilnowanie sreber rodowych ${ }^{38}$.

Zaprezentowana powyżej instrukcja świadczy, że zasygnalizowany na początku klasyczny schemat edukacji należy wzbogacić, w odniesieniu do męskich potomków Wacława Rzewuskiego, o czwarty typ wychowania obywatelskiego i dworskiego, ugruntowanego w tradycji europejskiej od czasów renesansu, a polegającego na kształceniu sfery obyczajowej i poznawaniu obowiązków związanych z konkretnymi urzędami, a także nabywaniu ogłady towarzyskiej oraz doświadczenia i obycia przez obracanie się w kręgach władzy, asystując u boku ojca w ważnych wydarzeniach publicznych. Ten element praktycznego kształcenia przyszłego polityka, męża stanu i wysokiego urzędnika państwowego z pewnością był postrzegany jako jeden z istotniejszych elementów całego toku edukacji. W nawiązaniu do tego wątku pragniemy przybliżyć drugą z tytułowych instrukcji przeznaczonych dla Seweryna. Ma ona charakter poradnika wojskowego, jak postępować w razie zagrożenia najazdem obcych wojsk ${ }^{39}$. W rękopisie widnieją dwie daty - 1763 oraz 8 Julii 1764, co może sugerować, że wskazania były udzielane przez ojca już wcześniej, a spisane dopiero w 1764 r. Instrukcja ta ma charakter pouczający

36 J. R. Snyder, Dissimulation and the Culture of Secrecy in Early Modern Europe, Londyn 2009, s. 12-13; M. Malinowska, Krytyka ideału honnêteté na tle nowoczesnych pogladów Poulaina de la Barre, „Acta Philologica" nr 43 (2014), s. 150-152.

37 D. Żołądź-Strzelczyk, Wychowanie dziecka w świetle staropolskiej teorii pedagogicznej, w: Od narodzin do wieku dojrzałego. Dzieci i młodzież w Polsce, cz. 1, Od średniowiecza do wieku XVIII, pod red. M. Dąbrowskiej i A. Klondera, Warszawa 2002, s. 98.

38 „Jan Kowal może być dodany do kredensu i sypia z drugiemi u srebra”; Informacyja synowi memu jak się ma sprawować w Warszawie, s. 216.

39 Informacyja synowi memu staroście dolińskiemu dana roku 1763; ANK, APodh II 2/95, s. 553; dalej cyt.: Informacyja synowi memu staroście Dolińskiemu. 
w kwestiach militarnych, a jej powstanie związane jest z ówczesną sytuacją polityczną, w której Seweryn Rzewuski, podobnie jak jego ojciec, był zdeklarowanym zwolennikiem obozu republikantów i znajdował się w opozycji antykrólewskiej. Instrukcja Wacława była wyrazem jego troski o dobra rodzinne i powstała w obawie przed odwetem wojsk rosyjskich za prowadzoną przez niego działalność sejmikową i sejmową oraz projekty skierowane przeciwko planom Stanisława Augusta Poniatowskiego zakładające wzmocnienie władzy królewskiej w oparciu o Rosję ${ }^{40}$. Treść instrukcji sprowadza się w zasadzie do drobiazgowego wyliczenia oczekiwań ojca w kwestii zachowania czujności i wzmocnienia straży na zamku w Podhorcach oraz w Olesku. Obawa najazdu na rodzinne rezydencje dotyczyła zresztą nie tylko regularnej armii rosyjskiej, ale także „zwyczajnej kupy” i ,partii przeciwnej”, pod którymi to terminami rozumiał on wojska wierne królowi i Familii. Dość powiedzieć, że instrukcja zawierająca wskazania dla Seweryna, wówczas już generała majora wojsk koronnych i „starszego syna” (czyli Józefa lub Stanisława Rzewuskiego) ostatecznie otrzymała kapitulancką konkluzję sprowadzającą się do stwierdzenia, aby opierać się jedynie niewielkim liczebnie oddziałom, zaś przed dużymi siłami politycznych adwersarzy złożyć broń i serdecznie ich ugościć: Bronić zaś się wielkiej komendzie i liczbie nie trzeba. Gościa z przeciwnej strony jak najlepiej przyjać, wygody jak największe czynić, a wina, choćby kilka beczek, nie żałowaćt1. Nie poświęcamy tym sprawom więcej uwagi, pragnąc jedynie zaznaczyć wszechstronność Wacława Rzewuskiego tworzącego na bieżąco instrukcje różnego typu dla swoich dzieci w reakcji na potrzebę chwili. Przytoczone fragmenty instrukcji świadczą również, że Seweryn znajdował się pod ścisłą kuratelą ojca właściwie do końca jego życia, czyli roku $1779^{42}$, a to uzależnienie i niesamodzielność datują się w zasadzie od samego początku jego kariery publicznej.

Ewenementem są natomiast dwie instrukcje skierowane do córek, które Wacław Rzewuski napisał, jak się wydaje, w stosunkowo krótkim odstępie czasu. Zasługują one na szczególną uwagę przede wszystkim z tego powodu, że znamy niewiele dokumentów zawierających wskazówki wychowawcze tego typu. Ograniczonej bazie źródłowej towarzyszy również niewielkie zainteresowanie tematem owocujące nielicznymi pracami analitycznymi ${ }^{43}$. Poniekąd jest to też zapewne wynikiem niewielkiego zaangażowania ideologów staropolskiej myśli pedagogicznej, którzy kwestii kształcenia kobiet poświęcali niewiele uwagi. Taka postawa twórców teorii pedagogicznych wynikała z przeświadczenia o konieczności realizowania przez kobiety głównie przypisanych im ról społecznych sprowadzających się do opieki nad dziećmi i dbałości o dom rodzinny ${ }^{44}$. Ewentualne

${ }^{40}$ K. Maksimowicz, Seweryna Rzewuskiego droga do Targowicy, Gdańsk 2002, s. 50.

${ }^{41}$ Informacyja synowi memu staroście Dolińskiemu, s. 553.

${ }^{42}$ K. Maksimowicz, Hetman Seweryn Rzewuski pod sterem swego ojca Wacława w latach 1774-1779, „Ze skarbca kultury” 1989, z. 49, s. 149-189.

${ }_{43}$ Zob. U. Augustyniak, Instrukcja Bogusława Radziwiłla dla opiekunów jego córki, Ludwiki Karoliny (przyczynek do edukacji młodej ewangeliczki w końcu XVII w.), „Odrodzenie i Reformacja w Polsce” 1991, t. XXXVI, s. 215-235.

${ }^{44}$ J. Freylichówna, Ideat wychowawczy szlachty polskiej w XVI i początku XVII w., Warszawa 1938, s. 155 . 
odstępstwa od tej reguły pozostawiano w gestii rodziców i opiekunów. Zasada ta dotyczyła głównie panien z bogatych rodzin szlacheckich i magnackich, wskutek czego żeńska edukacja nabierała charakteru elitarnego. W tym kontekście należy rozpatrywać dwie znane nam instrukcje Wacława Rzewuskiego dla swoich córek.

Pierwsza z instrukcji, która zawiera szczegółowe wskazówki odnoszące się do zasad organizacji krótkich wyjazdów z Podhorców, została napisana 10 lipca 1763 r. ${ }^{45}$ Edukacją i wychowaniem córek zajmowały się w głównej mierze matki, ale Anna Rzewuska z Lubomirskich zmarła przedwcześnie w 1763 r., mając wówczas niespełna 46 lat i to na osobie ojca spoczął obowiązek troski o przyszłość praktycznie dorosłych już wówczas córek. Spośród trojga potomków płci żeńskiej do wieku dojrzałego dożyły dwie córki. Starsza z nich Teresa Karolina miała wówczas już 21 lat i niebawem wyszła za mąż za Karola Stanisława Radziwiłła „Panie Kochanku”, jednego z najpotężniejszych polskich magnatów. Ślub odbył się 8 kwietnia 1764 w Podhorcach. Z kolei młodsza o dwa lata Ludwika Maria Róża poślubiła w 1766 r. starostę żmudzkiego Jana Mikołaja Chodkiewi$\mathrm{cza}^{46}$. Pragnąc zapewnić im jak najlepsze warunki oraz wyrazić swoje oczekiwania, Wacław zaledwie trzy tygodnie po śmierci małżonki spisał pierwszą ze znanych nam instrukcji jego autorstwa przeznaczonych dla córek. Zapewne z tego samego czasu pochodzi także druga instrukcja, która nie jest datowana, będąca w istocie głównie zbiorem przepisów przeciwpożarowych ${ }^{47}$. Polska literatura i praktyka pedagogiczna dotycząca wychowania kobiet zakładała generalnie stosowanie dwóch metod. Pierwsza, mająca charakter konserwatywny i zachowawczy, sprowadzała się przede wszystkim do kształtowania osobowości poprzez formację religijno-moralną oraz przygotowanie do roli żony, matki i gospodyni. Druga, zdecydowanie rzadziej spotykana, preferowała rozległą edukację na wzór męskiejej ${ }^{48}$ Zalecenia Rzewuskiego dla pełnoletnich już córek mają przede wszystkim zdroworozsądkowy charakter i sprawiają wrażenie chęci ich ustrzeżenia przed nieszczęśliwym wypadkiem czy niepożądanym towarzystwem. Pozwala to na konstatację, iż dwie instrukcje dla córek, będących wówczas w wieku ,przedmałżeńskim" miały na celu zapewnienie właściwej konduity, nad którą miała czuwać ich ochmistrzyni Kozłowska, przywoływana w tekście instrukcji. Planowane przez Wacława mariaże były ważnym instrumentem konstruowania sojuszy politycznych, o czym świadczy o kilka lat wcześniejszy (1758) plan wydania za mąż młodszej z córek Ludwiki za syna ministra królewskiego Henryka Brühla, co jednak nie doszło do skutku ${ }^{49}$. Ze względu na dość zaawansowany wiek córek zapisy instrukcji nie odnoszą się natomiast w ogóle do kwestii edukacyjnych, nie dając kompletnie żadnej wiedzy na temat wykształcenia

\footnotetext{
45 Dyspozycya około przejażḋki moich córek R.P. 1763 die 10 Julii w Podhorcach.; ANK, APodh II 131, s. 343; dalej cyt.: Dyspozycya około przejażdżki moich córek.

46 Z. Zielińska, Rzewuski Wacław h. Krzywda, op. cit., s. 179.

47 Dyspozycya około ostrożności od ognia w stancyi moich córek, Archiwum Narodowe w Krakowie (Wawel), APodh II 131, s. 343-344; dalej cyt.: Dyspozycya około ostrożności od ognia w stancyi moich córek.

48 D. Żołądź-Strzelczyk, „Jako rządzić mają rodzice córki swe”. Poglady na wychowanie kobiet w XVI-XVIII w., w: Rola $i$ miejsce kobiet $w$ edukacji $i$ kulturze polskiej, t. 1, pod red. W. Jamrożka i D. Żołądź-Strzelczyk, Poznań 1998, s. 56.

49 L. Rzewuski, op. cit., s. 38.
} 
córek Rzewuskiego. Należy przypuszczać, iż odbywało się ono wedle mody przyjętej w polskim środowisku magnackim, obejmując edukację domową pod opieką guwernantki oraz być może naukę w którejś z żeńskich szkół klasztornych ${ }^{50}$.

Instrukcja sporządzona latem 1763 r. obejmowała wskazówki odnoszące się do realiów podróżowania po okolicy zamieszkania młodych magnatek. Określono w niej główne cele wyjazdów oraz ich szczegółową chronologię. Jej odczytanie nastręcza pewnych problemów, ponieważ Wacław Rzewuski opisał bardzo ogólnikowo, oczywiste dla siebie i adresatek, cztery docelowe miejsca krótkich wycieczek z Podhorców. W dziewięciu punktach autor zamknął kolejne wskazania regulujące harmonogram i warunki podróżowania. Z nazwy wymieniono tylko trzy miejscowości. Najczęściej miano wyjeżdżać do „monasteru”, a przejażdżki te przewidziano pięć razy w miesiącu - dnia pierwszego, ósmego, dwunastego, szesnastego i dwudziestego. Wacław Rzewuski nie sprecyzował, o jaki klasztor chodzi. Biorąc pod uwagę dużą częstotliwość tych wyjazdów, implikuje ona chyba bardzo nieznaczną odległość. Nie może tu jednak chodzić o kościół i klasztor bazylianów w samych Podhorcach, gdyż ten dopiero budowano z fundacji Wacława Rzewuskiego (wprawdzie już od 1752 r.), ale konsekrowany został dopiero w 1766 r. ${ }^{51}$ Być może wzmianka ta dotyczyła monasteru we Lwowie, do którego jednak z Podhorców trzeba było pokonać dość długą trasę. Oprócz tego 25 dnia każdego miesiąca można było wybrać się do Oleska, zaś 29 do Dubna lub Hołoskowic. Miały to być bardzo krótkie wypady rozpoczynane po południu, a kończone przed zmierzchem żeby za widoku być w zamku $u^{52}$. W przypadku Oleska i Hołoskowic było to zadanie w pełni uzasadnione, gdyż od Podhorców dzieli je stosunkowo niewielka odległość kilkunastu kilometrów. Natomiast wyprawa do Dubna musiała być dłuższym przedsięwzięciem, biorąc pod uwagę znaczny dystans do pokonania. Celami podróży były kompleksy dóbr i rezydencje należące do Rzewuskich lub ich krewnych. W Olesku znajdował się zamek Rzewuskich, a w tamtejszym kościele pochowana była żona Wacława Rzewuskiego i matka jego dzieci Anna z Lubomirskich. W oleskim kościele kapucynów spoczywali również zmarli w dzieciństwie czterej synowie Rzewuskich oraz jedna z córek ${ }^{53}$. Z kolei w Dubnie na zamku rezydowali Lubomirscy, spokrewnieni z pannami Rzewuskimi ze strony ich matki.

Instrukcja zawierała też wyraźnie wyartykułowane zalecenia narzucające sposób bycia gwarantujący odpowiedni poziom magnackiej ostentacji oraz zachowanie dobrej konduity. W tym celu ojciec przykazywał podróżowanie wyłącznie w małym orszaku składającym się ze służby oraz guwernantki nadzorujących bezpieczeństwo i właściwe zachowanie podopiecznych podczas podróży. W mikroskali było to skopiowanie wzorów organizacji i zadań orszaków towarzyszących synom magnackim w trakcie zagranicz-

50 D. Żołądź-Strzelczyk, W. Jamrożek, Studia z dziejów edukacji kobiet na ziemiach polskich, Poznań 2001, s. 45-75.

\footnotetext{
51 A. Szyszko-Bohusz, Podhorce, „Sztuki Piękne” 1925, R. I, nr 4, s. 160-162.

${ }^{52}$ Dyspozycya około przejażdżki moich córek, s. 343.

${ }^{53}$ L. Rzewuski, op. cit., s. 24.
} 
nych podróży edukacyjnych ${ }^{54}$. Oczywiście w tym przypadku trzeba brać pod uwagę daleko idącą odmienność tego wzorca wynikającą ze specyfiki podróży kobiecych. Świta Teresy Karoliny oraz Ludwiki Marii Róży Rzewuskich miała składać się z przynajmniej sześciu osób, wśród których najważniejszą rolę odgrywała ochmistrzyni Kozłowska, jedna panna do towarzystwa, stangret, „dworzanin” jadący przed powozem oraz co najmniej dwóch lokajów obsługujących karetę. Ogólny nadzór miała sprawować „Jejmość Pani Kozłowska", a w razie jej choroby najstarsza dwórka z magnackiego fraucymeru Rzewuskich. Także służba i oficjaliści dworscy otrzymali szczegółowe wskazówki dotyczące przygotowania tych wyjazdów. Koniuszy podhorecki Rulikowski, lub w jego zastępstwie podkoniuszy, miał wybierać do zaprzęgu wyłącznie sprawdzone, spokojne konie, unikając zaprzęgania „swywolnych do karety, ale najpodufalsze”. Troska o bezpieczeństwo przejazdu została również wyrażona w kategorycznym poleceniu dla stangretów, aby ci temperowali konie i powozili karetą w umiarkowanym tempie ${ }^{55}$.

Druga z instrukcji spisanych dla córek pochodzi zapewne również z 1763 r. i dotyczy kwestii zachowania bezpieczeństwa podczas pobytu w Podhorcach. Dokument ten nie przynosi również informacji na temat wykształcenia córek Rzewuskiego, które zapewne sprowadzało się do odebrania edukacji domowej. Wprawdzie w połowie XVIII w. coraz popularniejsze w środowisku szlacheckim i magnackim było posyłanie młodych córek na pensję prowadzoną przez zakony żeńskie, szczególnie wizytki i sakramentki ${ }^{56}$. Nie posiadamy jednak informacji o podobnym wykształceniu odebranym przez Teresę Karolinę i Ludwikę Marię Rzewuskie. Wspomniana instrukcja odnosi się zaś do bezpiecznego przebywania w zamku Podhoreckim, co sugeruje użyta nazwa pokoju mozaikowego znajdującego się na pierwszym piętrze kompleksu pałacowego. W pokoju tym, wyposażonym w bogaty wystrój obrazowy, znajdowała się sypialnia Anny z Lubomirskich Rzewuskiej. Tam także wisiał jej portret ${ }^{57}$. Zalecenia ojca koncentrowały się przede wszystkim na wielokrotnie powtarzanym zakazie pozostawiania bez nadzoru zapalonych świec, lamp czy ognia w kominkach bądź żelazkach. Źródła światła mogły się znajdować jedynie w wyznaczonych miejscach i to takich, które wykluczały wszelkie zagrożenie pożarem: to opodal od rzeczy, które by się mogli zajać, osobliwie od firanek ${ }^{58}$. Specjalny dozór został zlecony znanej już ochmistrzyni Kozłowskiej, która miała dopilnować zabezpieczenia skrzyń, kufrów oraz mebli i odseparowania wszelkich sprzętów w bezpiecznych pomieszczeniach.

Uwagę badacza przykuwają niezwykle drobiazgowe i w wielu momentach zupełnie oczywiste wskazówki dotyczące nawet elementarnych zasad dbałości o zdrowie czy za-

\footnotetext{
54 Zob. M. Chcachaj, Orszak młodego magnata odbywającego podróż edukacyjna (wiek XVI-XVIII), w: Patron i dwór. Magnateria Rzeczypospolitej w XVI-XVIII wieku, pod red. E. Dubas- Urwanowicz i J. Urwanowicza, Warszawa 2006, s. 165-178.

55 Dyspozycya około przejażdżki moich córek, s. 343.

${ }^{56}$ B. Wlaźlik, Wychowanie dziewcząt w XVI i XVII w., „Prace Naukowe akademii im. Jana Długosza w Częstochowie" 2008, Pedagogika, t. XVII, s. 208.

${ }^{57}$ S. Przyłęcki, Opisanie pałacu w Podhorcach, w: Dniestrzanka. Zbiór artykułów wierszem i proza wydanych ku zabawie i nauce, wyd. S. Jaszowski, Lwów 1841, s. 12.

${ }^{58}$ Dyspozycya około ostrożności od ognia $w$ stancyi moich córek, s. 344.
} 
chowanie bezpieczeństwa w prostych sytuacjach dnia codziennego. Każe to zastanowić się nad faktycznymi powodami roztoczenia tak ścisłego nadzoru nad wychowaniem dzieci i wielokrotnym powtarzaniem podobnych lub nawet takich samych wskazówek. Jak się wydaje można wskazać przynajmniej dwa prawdopodobne źródła nadprodukcji, a nawet grafomanii Wacława Rzewuskiego. Jedną z przyczyn może być samo zamiłowanie do słowa pisanego i pasja literacka, chociaż język instrukcji nie wyróżnia się ani wyszukaną ozdobnością, ani bogactwem użytych zwrotów czy pięknem sformułowań, mimo iż sam Rzewuski cieszył się sławą zdolnego i płodnego twórcy. Ważniejsze wydają się być jednak koleje życia rodzinnego, a w szczególności śmierć kilkorga potomków w dzieciństwie, które odcisnęły się piętnem straty i żalu w uczuciowości Wacława i jego żony. Według opinii badaczy mogło to wpłynąć na ukształtowanie się inklinacji do nadopiekuńczości u Rzewuskiego, szczególnie po śmierci żony ${ }^{59}$. Taka teza wydaje się najbardziej prawdopodobna.

Instrukcje rodzicielskie Wacława Rzewuskiego przedstawione powyżej zawierają zarówno zalecenia wychowawcze, jak i wskazówki logistyczne dotyczące organizacji podróży i pobytu jego dzieci tak w dobrach i rezydencjach rodzinnych, jak i poza nimi. Charakterystycznym rysem zaprezentowanych tu instrukcji jest prawie całkowity brak zagadnień edukacyjnych. Tego deficytu nie są w stanie zrównoważyć ogólne zalecenia dotyczące nakazów lektury i nauki skierowanych do Seweryna. Dominuje troska o zdrowie, bezpieczeństwo, chronienie dóbr oraz właściwą postawę moralną potomstwa. Jednocześnie można zauważyć, że Wacław Rzewuski w formułowaniu rodzicielskich nakazów bazuje przede wszystkim na własnym doświadczeniu, nie odwołując się do żadnych autorytetów ani idei uznanych nurtów pedagogicznych. Może to być skutkiem pewnego pośpiechu widocznego $\mathrm{w}$ ich redakcji oraz $\mathrm{w}$ ich przeznaczeniu na określoną sytuację i dość krótki czas, a nie założonego na długofalowy proces wychowawczy, tym bardziej, że trzy z czterech analizowanych instrukcji przeznaczone zostały dla już dorosłych dzieci. Istotna wartość zaprezentowanych instrukcji, szczególnie w odniesieniu do informacji napisanej dla syna Seweryna, polega na doprecyzowaniu instruktażowym kształcenia dworskiego pozwalającego realizować ideał honnête homme. W tym wypadku instrukcja nie ma charakteru ogólnego, lecz jest poświęcona konkretnemu wycinkowi czasu. Prezentuje jednak uniwersalne wymogi i oczekiwania ojca względem syna, których przestrzeganie wraz ze zdobytym wykształceniem i koneksjami miało, jak wierzono, przynieść w nieodległej przyszłości wymierną korzyść w nawiązywaniu relacji towarzyskich oraz osiąganiu sukcesów politycznych i awansów urzędniczych. Instrukcje adresowane do córek, zawierające przede wszystkim zestaw pouczeń i nakazów mających zapewnić im bezpieczeństwo, wyrażają autentyczną troskę ojca o ich zdrowie i pomyślną przyszłość mieszczącą się w ogólnie przyjętym modelu życia młodych przedstawicielek polskiej magnaterii.

\footnotetext{
${ }^{59}$ K. Maksimowicz, Seweryna Rzewuskiego..., s. 17-20.
} 


\section{Bibliografia}

Augustyniak U., Instrukcja Bogusława Radziwiłła dla opiekunów jego córki, Ludwiki Karoliny (przyczynek do edukacji młodej ewangeliczki w końcu XVII w.), „Odrodzenie i Reformacja w Polsce" 1991, t. XXXVI, s. 215-235.

Bratuń M., ,, Ten wykwintny, wyksztatcony Europejczyk”. Zagraniczne studia i podróże edukacyjne Michała Jerzego Wandalina Mniszcha w latach 1762-1768, Opole 2002.

Chcachaj M., Orszak młodego magnata odbywającego podróż edukacyjna (wiek XVI-XVIII), w: Patron i dwór. Magnateria Rzeczypospolitej w XVI-XVIII wieku, pod red. E. Dubas-Urwanowicz i J. Urwanowicza, Warszawa 2006.

Czaplewski P., Górski Ludwik Stanisław (1725-1799), PSB, t. 8, Wrocław 1959-1960.

Czapliński W., Długosz J., Życie codzienne magnaterii polskiej w XVII w., Warszawa 1982.

Diarjusze sejmowe z wieku XVIII, t. III, Diariusze sejmów z lat 1750, 1752, 1754 i 1758, wyd. W. Konopczyński, s. 286.

Dramat staropolski od początków do powstania sceny narodowej. Bibliografia, t. 2 , cz. 2, Programy drukiem wydane do r. 1765. Programy teatru pijarskiego oraz innych zakonów i szkót katolickich, opr. W. Korotaj, J. Szwedowska, M. Szymańska, Wrocław 1978.

Dyspozycya około ostrożności od ognia w stancyi moich córek, Archiwum Narodowe w Krakowie (Wawel), APodh II 131, s. 343-344; dalej cyt.: Dyspozycya około ostrożności od ognia w stancyi moich córek.

Dyspozycya około przejażdżki moich córek R.P. 1763 die 10 Julii w Podhorcach.; ANK, APodh II 131.

Freylichówna J., Ideat wychowawczy szlachty polskiej w XVI i początku XVII w., Warszawa 1938.

Gad P., ,Ojcowskim sercem i stowem” - Instrukcja wychowawcza autorstwa Hieronima Floriana Radziwilta, „Ogrody Nauk i Sztuk” 2016, 6.

Graciotti S., Od Renesansu do Oświecenia, t. 2, Warszawa 1991.

Informacya synowi memu Józefowi dana w Podhorcach R.P 1755 D. 14 Augusti; Muzeum Narodowe w Krakowie, rkps 22, k. 207v.-208.

Informacya synowi memu Sewerynowi do Wiednia i dalszych cudzych krajów jadącemu dana dnia 14 februarii roku pańskiego 1759 w Podhorcach; Archiwum Narodowe w Krakowie (Wawel), APodh I 126, s. 383-384

Informacyja synowi memu jak się ma sprawować w Warszawie. Archiwum Narodowe w Krakowie, oddział na Wawelu, Archiwum Podhoreckie (dalej cyt.: APodh) II 230, s. 215-216.

Informacyja synowi memu staroście dolińskiemu dana roku 1763; ANK, APodh II 2/95, s. 553; dalej cyt.: Informacyja synowi memu staroście Dolińskiemu.

Konopczyński W., Chronologia sejmów polskich 1493-1793, Kraków 1948.

Kurdybacha Ł., Kolegium teatynów w Warszawie, w: Historia wychowania, t. 1, pod red. Ł. Kurdybachy, Warszawa 1967.

Kurdybacha Ł., Pedagogika szlachecka $w$ XVI i XVII w. w świetle instrukcji rodzicielskich, w: idem, Pisma wybrane, opr. J. Miąso, t. 3, Warszawa 1976.

Łempicki S., Polski ideat wychowawczy, Lwów-Warszawa 1937.

Maksimowicz K., Hetman Seweryn Rzewuski pod sterem swego ojca Wacława w latach 1774-1779, „Ze skarbca kultury” 1989, z. 49.

Maksimowicz K., Młodość i początki dziatalności publicznej Seweryna Rzewuskiego (lata 1743-1767), „Ze skarbca kultury” 1989, z. 48.

Maksimowicz K., Seweryna Rzewuskiego droga do Targowicy, Gdańsk 2002.

Maksimowicz K., W sprawie Collegium Varsaviense ojców teatynów, w: Europejskie związi dawnego teatru szkolnego i europejska wspólnota dawnych kalendarzy, pod red. I. Kadulskiej, Gdańsk 2003. 
Parysiewicz B., Z badań nad rozwojem polskiej myśli pedagogicznej o wychowaniu w rodzinie, $\mathrm{w}$ : Wychowanie $w$ rodzinie od starożytności po wiek XX. Materiaty z konferencji naukowej Katedry Historii wychowania czerwiec 1993, pod red. J. Jundziłła, Bydgoszcz 1994.

Poraziński J., ,, Statysta głęboki”. Kilka uwag o erudycji staropolskich polityków, w: Między barokiem a oświeceniem. Edukacja, wykształcenie, wiedza, pod red. S. Achremczyka, Olsztyn 2005.

Przyłęcki S., Opisanie pałacu w Podhorcach, w: Dniestrzanka. Zbiór artykułów wierszem i proza wydanych ku zabawie i nauce, wyd. S. Jaszowski, Lwów 1841.

Puchowski K., Edukacja „losem urodzenia wyznaczonych $w$ warszawskim kolegium teatynów (1737-1785), w: Między barokiem a oświeceniem. Sarmacki konterfekt, pod red. S. Achremczyka, Olsztyn 2002.

Puchowski K., Przemiany w szkolnictwie zakonnym Rzeczypospolitej czasów saskich, w: Między barokiem a oświeceniem. Edukacja, wyksztatcenie, wiedza, pod red. S. Achremczyka, Olsztyn 2005.

Rzewuski L., Kronika podhorecka 1706-1779, Kraków 1860.

Stownik Geograficzny Królestwa Polskiego i Innych Krajów Stowiańskich, t. 3, Warszawa 1882.

Snyder J.R., Dissimulation and the Culture of Secrecy in Early Modern Europe, Londyn 2009, s. 12-13; M. Malinowska, Krytyka ideału honnêteté na tle nowoczesnych poglądów Poulaina de la Barre, „Acta Philologica”, nr 43 (2014).

Szyszko-Bohusz A., Podhorce, „Sztuki Piękne” 1925, R. I, nr 4.

Waniczkówna H., Caraccioli Ludwik Antoni de (1721-1803), PSB, t. 3, 1937.

Wlaźlik B., Wychowanie dziewcząt w XVI i XVII w., „Prace Naukowe akademii im. Jana Długosza w Częstochowie" 2008, Pedagogika, t. XVII.

Zatorska I., Les Polonais en France 1696-1795. Bio-bibliographie provisoire, Warszawa 2000.

Zielińska Z., Rzewuski Seweryn, PSB, t. 34, 1992-1993.

Zielińska Z., Rzewuski Wacław h. Krzywda (1706-1779), Polski Słownik Biograficzny, t. 34, 1992 1993.

Żołądź D., Ideały edukacyjne doby staropolskiej. Stanowe modele i potrzeby edukacyjne szesnastego i siedemnastego wieku, Warszawa-Poznań 1990.

Żołądź D., Rodzina szlachecka jako środowisko wychowawcze (XVI-XVII w.), w: Wychowanie w rodzinie od starożytności po wiek $X X$.

Żołądź-Strzelczyk D., „Jako rządzić maja rodzice córki swe”. Poglady na wychowanie kobiet w XVI-XVIII w., w: Rola i miejsce kobiet w edukacji i kulturze polskiej, t. 1, pod red. W. Jamrożka i D. Żołądź-Strzelczyk, Poznań 1998.

Żołądź-Strzelczyk D., Jamrożek W., Studia z dziejów edukacji kobiet na ziemiach polskich, Poznań 2001.

Żołądź-Strzelczyk D., Wychowanie dziecka w świetle staropolskiej teorii pedagogicznej, w: Od narodzin do wieku dojrzałego. Dzieci i młodzież w Polsce, cz. 1, Od średniowiecza do wieku XVIII, pod red. M. Dąbrowskiej i A. Klondera, Warszawa 2002. 
